\title{
Economic Consequences of Disaggregate Energy Consumption in West African Countries
}

\author{
Olabode Philip Olofin ${ }^{1}$, Olaolu R. Olayeni ${ }^{2} \&$ Opeyemi P. Abogan ${ }^{2}$ \\ ${ }^{1}$ Department of Economics, Obafemi Awolowo University, Ile-Ife, Nigeria \\ ${ }^{2}$ Department of Economics, Osun State College of Education, Ilesha, Nigeria \\ Correspondence: Olabode Philip Olofin, Department of Economics, Obafemi Awolowo University, Ile-Ife, \\ Nigeria. Tel: 234-803-380-9505. E-mail: opolofin@oauife.edu.ng
}

Received: December 30, 2013 Accepted: May 1, 2014 Online Published: May 7, 2014

doi:10.5539/jsd.v7n3p71

URL: http://dx.doi.org/10.5539/jsd.v7n3p71

\begin{abstract}
Using the data over the period 1971-2010 and employing Dynamic Ordinary Least Squares for Cointegrated Panel Data with homogeneous long-run covariance structure across cross-sectional units, this paper assesses the costs of disaggregate energy consumption on the growth of output and of its components in eight selected West African Countries. The results show that fossil fuel consumption affects industry and agriculture negatively and positively affects per capita output growth, with none of the results statistically significant. There is positive relationship between electricity consumption and industry with statistically significant result. However, there is negative relationship between electricity consumption, agriculture and per capita output growth rate and the results were not statistically significant. Also, there is positive relation between road energy consumption, agriculture and output growth rate with statistically significant results. We find negative relation between diesel consumption, agriculture and output growth rate, but the relation between diesel consumption and industry is positive. However, none of these results is statistically significant. The study concludes that high priority should be placed on constant and stable supply of electricity and road energy.
\end{abstract}

Keywords: disaggregate energy, growth components, panel dynamic ols, west africa

\section{Introduction}

Based on the importance of energy consumption and the intention to improve energy efficiency as well as mitigating the level of pollution and global warming, there has being an increase in the number of studies on the relation between energy consumption and economic growth in the last decades (see Kraft \& Kraft, 1978; Chontanawat, Hunt, \& Pierse, 2008; Wolde-Rufael, 2005, 2006, 2009; Akinlo, 2008; Tsani, 2010; Olayeni, 2012; Tamba, Njomo, Limanond, \& Ntsafack, 2012; Fuinhas \& Marques, 2012). While energy-growth nexus has been discussed at length, the literature has not taken the advantage of disaggregate components of both energy and economic growth data. It has been noted that examining the nexus between the components of energy and economic growth allows the advantage of comparing the strengths of causal relationships by energy resources (Sari, Ewing, \& Soytas, 2008). According to Yang (2000), using disaggregate energy consumption provides an avenue to determine the extent by which countries depend on different types of energy. This study argues further that, exploring the advantage of components of both energy and growth goes a long way in identifying the channels through which energy affects the economy, and the extent by which each component of the economy depends on a specific type of energy.

Much of the existing literatures focus on the impact of total or a component of energy consumption on aggregate or a component of economic activity (Olayeni, 2012; Lorde, 2010; Akinlo, 2008, 2009; Narayan \& Smyth, 2005; Fatai, Oxley, \& Scrigeour, 2004; Oh \& Lee, 2004; Thoma, 2004; Ghosh, 2002). Aside from the study of Sari, Ewing, and Soytas (2008) which examine the impact of disaggregated energy consumption such as coal, fossil fuels, conventional hydroelectric power, solar energy, wind energy, natural gas, wood, and waste consumption on industrial production and employment, and that of Kwakwa (2012) who examined the impact of disaggregated energy consumption on overall growth, manufacturing growth and agricultural growth in Ghana, only few, if it exists, has systematically and empirically analyzed the relationship between disaggregated energy consumption and components of economic aggregates despite data availability. 
Following the fact that, agricultural growth is the most important contributor to manufacturing and service activity in African countries, it is also not only energizing agro-industries, but the overall economy as well. According to Haggblade et al. (1989) as cited in Cleaver (1993) and Stoneman and Robinson (1987), each unit increase in agricultural activity leads to approximately 1.5 units of economic growth. On-farm activities comprise energy-intensive operations, such as irrigation, traction, drying and curing. Although, the use of diesel, gasoline and electricity in agriculture sector in West Africa might not be as pronounced as in developed countries (see Lokolo, 1994), but it is still noted that electricity is part of the energy required for agricultural operation and processing. More so, the few available industries in West Africa rely on energy especially diesel energy. Most available studies focus on the relation between electricity and growth, neglecting the fact that electricity itself is highly unstable, and that diesel energy serves as the last and reliable source of energy for components of economic activities in West Africa. Thus, examining the relation between disaggregates energy and the components of output in West Africa is justified in this study. The paper therefore, re-examines and contributes to the findings on whether and how the economic cost of energy consumption (i.e. fossil, road energy, electricity and diesel energy consumption) varies with the type of output and across economic aggregates (i.e. industry, agriculture and growth rate of output) in Benin, Cameroon, Cote d'ivoire, Gabon, Ghana, Nigeria, Senegal and Togo. The paper posits that different types of energy can affect different economic aggregates differently and that if a component of an aggregate is affected by a shock, while others are not, addressing the aggregate instead of focusing on the affected component will strongly be a wrong policy target. The remainder of the paper is organized as follows. Section 2 briefly reviews the literature, section 3 discusses the method, sources of data and measurement of variables. Section 4 presents the estimated models, section 5 discusses the results, while section 6 presents concluding remarks.

\section{A Brief Literature Review}

Four possible channels of relation have been established on the issue of energy-growth relation. These are growth; conservation; neutrality and feedback hypothesis (Note 1). Unfortunately results on these channels are mixed. For example, the studies that found neutral connection between energy and economic growth are the studies of Jobert and Karanfil (2007), Lee (2006), Zachariadis (2007), Chiou-Wei et al. (2008), Yuan et al. (2008), Halicioglu (2009), Payne (2009), Soytas and Sari (2009) and Wolde-Rufael (2009). Thosethat found positive relation running from energy to growth are: Climent and Pardo (2007), Ang (2007), Narayan and Smyth (2008), Odhiambo (2009), Tsani (2010), and Pereira and Pereira (2010). Those that found relation running from output to energy are: Soytas and Sari (2006), Lee (2006), Zachariadis (2007), Zamani (2007), Mehrara (2007), Lise and Van Montfort (2007), Those that found bi-directional relation between energy and growth are: Zachariadis (2007), Mahadevan and Asafu- Adjaye (2007), Erdal et al. (2008), Belloumi (2009) and Mishra et al. (2009). Mixed results have been associated with differences in characteristics of countries in terms of energy supply, political and economic history, political arrangement, and culture and energy policy, data and methodologies adopted (see Chen, Kuo, \& Chen, 2007).

On data measurement for example, some studies used gross domestic product (GDP) to measure income. This has been criticized on the basis of black economy that may cause it to be underestimated (Karanfil, 2008). Some used industrial output (Ziranmba, 2009) and some used public expenditure as a measure of economic activity (Ahsan, Kwan, Salni, 1992; Cheng \& Lai, 1997; Glasure, 2002). However, Jumbe (2004) distinguished between overall GDP, agricultural GDP and non agricultural GDP. Aside from the above, some studies that examine energy-income relation regressed disaggregate energy consumption on just a component of GDP. Other studies such as Akinlo (2009), examined the relationship between electricity consumption (a component of energy consumption) and aggregate output in Nigeria, and Olayeni (2012) used aggregate of both energy and income for 12 sub-Sahara African countries and also employed bivariate modeling approach. This method has also been criticized on the ground that it does not allow for evaluation of substitution effect of energy with other economic variables. Moreso, using bivariate analysis could result into loss in power especially when using small sample size as we have in this study and there could be danger of omitted variable bias (see Stern, 1993; Akinlo, 2009). This study suggests that if unrecorded economic activities occur in an economy, it may not in all the components of GDP. Based on the above therefore, the study uses multivariate models to examine the relation between disaggregate energy consumption and components of GDP, noting that there is possibility that, aggregate economic variable might not be seriously affected by energy consumption, but its components. It therefore argues that, determining the economic cost of different energy consumption on sectors contribution to GDP will enhance policy target. 


\section{Data and Methods}

The study uses annual data on disaggregate energy and sectors contribution to GDP of eight West African Countries as collected from the Energy Information Administration (EIA) 2011 and World data Bank African Development Indicators (ADI), 2011. Fossil is expressed in (thousand short tons), road energy in (thousand barrel per day), diesel in (thousand barrel per day) and electricity in (billion KWh). The countries under investigation were selected based on first; the availability of data and second; they share almost the same characteristics. It has been noted by Lloyd, Morrissey and Osei (2001) that pooling countries with different underlying time series property leads, very often, to misleading results and that differences in countries' characteristics can result into mixed results in energy-growth relations (Chen, Kuo, \& Chen, 2007). Thus, the assumptions about the homogeneity of parameter estimates and the data generating process are likely to hold, if we examine only the countries that share almost the same characteristics. The study employs the method of Kao and Chiang (2000) Dynamic Ordinary Least Squares for Cointegrated Panel Data with homogeneous long-run covariance structure across cross-sectional units.

\section{Models}

Three models where industry, agriculture and output per capita growth rate were specified as dependent variables were estimated in the study. Initial value of real GDP per capita is included as a control variable in all specifications. However, as a simple control to check the possibility of growth rates of output and of its components depending on the income at the initial period of the study, its coefficients were not reported. Each specification is estimated using lag of 3 and lead of 4 . All data are in their real terms and natural logarithm. The sample period is between 1971 and 2010. The models estimated in the study are:

$$
\begin{aligned}
& \text { industry }=\mathrm{f}(\text { fosfuelcons, electrcons, rodenergycons, dieselcons, inigdp }) \\
& \text { agriculture }=\mathrm{f}(\text { fosfuelcons, electrcons, rodenergycons, dieselcons, inigdp) } \\
& \text { gdppkgro }=\mathrm{f}(\text { fosfuelcons, electrcons, rodenergycons, dieselcons, inigdp) }
\end{aligned}
$$

where fosfuelcons $=$ fossil fuel consumption, electrons $=$ electricity consumption, rodenergycons $=$ road energy consumption, dieselcons $=$ diesel consumption and inigdp $=$ income at the initial period .

Table 1. Results of the study

\begin{tabular}{llll}
\hline & model(1) & model(2) & model(3) \\
\hline & Industry & agriculture & Gdppkgro \\
\hline \multirow{2}{*}{ fosfuelcons } & -0.0184 & -0.127 & 0.0127 \\
& $(-0.18)$ & $(-1.29)$ & $(0.49)$ \\
eletrcons & $0.0201^{* *}$ & $-0.0228^{* * *}$ & -0.00126 \\
& $(2.83)$ & $(-3.39)$ & $(-0.71)$ \\
rodenergycons & -0.0293 & $0.134^{* * *}$ & $0.0207^{* * *}$ \\
& $(-1.32)$ & $(6.39)$ & $(3.77)$ \\
dieselcons & 0.0109 & -0.00255 & -0.000375 \\
& $(1.02)$ & $(-0.25)$ & $(-0.14)$ \\
$\mathrm{N}$ & 124 & 124 & 124 \\
\hline
\end{tabular}

Note: $\mathrm{t}$ statistics in parentheses;

$* \mathrm{p}<0.05, * * \mathrm{p}<0.01, * * * \mathrm{p}<0.001$.

\section{Discussion of the Results}

Based on the importance of fossil fuel, road energy, diesel and electricity to the few available industries in West Africa, positive relations among them are expected. However, our results show positive relation among diesel, electricity and industries. This result corroborates that of Kwakwa (2012) where electricity is noted to be an important determinant factor in manufacturing industries. The negative relation among road energy, fossil fuel and industries could be as a result of high cost of operating industries with road energy and fossil fuel instead of electricity that is cost-effective. We find negative relation among agriculture, fossil fuel, electricity and diesel 
with statistically significant relation between agriculture and electricity. Typically, irrigation is provided using electric or diesel-powered pumps, but in a situation where grid electricity that is most reliable and least expensive is not available, use of more electricity can retard output. This is possible if consistent wetting of farmland failed or the operation is carried out at unaffordable cost. The statistical positive relation between road energy and agriculture may be due to the fact that most agricultural product in West Africa use road energy in processing and transportation. While agricultural sector has the potential of becoming a major source of bioenergy supply, providing liquid fuel substitutes, diesel and feedstocks for electricity production, and solid fuels for crop curing and drying, it relies mainly on the use of diesel in West African Countries. Most of the machines used in agriculture in West Africa are imported and they are not likely to be cost effective. For output, road energy and fossil fuel, positive relation is found. Only road energy is statistically significant. Electricity, diesel and output were found to be negatively related. This result is in contrast with that of Akinlo (2009) where electricity is found to be an important factor in output growth in Nigeria, although, he stated that caution should be taken in the interpretation of the result due to danger of omitted variable bias.

\section{Concluding Remarks}

This paper is premised on examining the economic costs of disaggregate energy consumption on different economic aggregates with the assumption that they may affect each other differently, and thereby causing confusion in policy target. It is found that, indeed, the cost of components of energy varies widely. Fossil fuel consumption affects industry and agriculture negatively and positively affects per capita output growth, with none of the results statistically significant. There is positive relationship between electricity consumption and industry with statistically significant result. This result suggests that stable electricity supply is highly essential industrial growth in West Africa. However, there is negative relationship between electricity consumption, agriculture and per capita output growth rate and the results were not statistically significant. Also, there is positive relation between road energy consumption and agriculture and output growth rate with statistically significant results. These results also suggest that, for agricultural and output growth, road energy consumption must be stable. Also, we find negative relation between diesel consumption, agriculture and output growth rate, but the relation between diesel consumption and industry is positive. However, none of these results is statistically significant. The findings in the study show that the benefits of estimating the impacts of energy in totality - both in relation to energy components and the effects on the economic aggregate - will allow policy makers to draw new and useful conclusions on the channels through which energy consumption affects the economy. The study suggests that energy policies in countries studied should place high priority in ensuring constant and stable supply of electricity and road energy. Therefore, when developing industry is the policy objective, stable electricity and diesel energy could be focused and when developing agriculture and increasing output are the targeted goals, road energy consumption could be the right target.

\section{References}

Ahsan, S. M., Kwan, A. C. C., \& Salni, B. S. (1992). Public expenditure and national income causality: further evidence on the role of omitted variables. Southern Economic Journal, 58, 621-632. http://dx.doi.org/10.2307/1059830

Akarca, A. T., \& Long, T. V. (1979). Energy and employment: a time series analysis of the causal relationship. Resources Energy, 2, 151-162. http://dx.doi.org/10.1016/0165-0572(79)90027-6

Akinlo, A. E. (2008). Energy consumption and economic growth: evidence from 11 African Countries. Energy Economics, 30, 2391-2400. http://dx.doi.org/10.1016/j.eneco.2008.01.008

Akinlo, A. E. (2009). Electricity consumption and economic growth in Nigeria: Evidence from cointegration and co-feature analysis. Journal of Policy Modelling, 31, 681-693. http://dx.doi.org/10.1016/j.jpolmod.2009.03.004

Ang, J. B. (2007). $\mathrm{CO}_{2}$ emissions, energy consumption, and output in France. Energy Policy, 35, 4772-4778. http://dx.doi.org/10.1016/j.enpol.2007.03.032

Belloumi, M. (2009). Energy consumption and GDP in Tunisia: Cointegration andcausality analysis. Energy Policy, 37(7), 2745-2753. http://dx.doi.org/10.1016/j.enpol.2009.03.027

Chen, S. T., Kuo, H. I., \& Chen, C. C. (2007). The Relationship Between GDP and Electricity Consumption in 10 Asian Countries. Energy Policy, 35, 2611-2621. http://dx.doi.org/10.1016/j.enpol.2006.10.001

Cheng, B. S., \& Lai, T. W. (1997). An investigation of cointegration and causality between energy consumption and economic activity in Taiwan Province of China. Energy Economics, 19, 435-444. http://dx.doi.org/10.1016/S0140-9883(97)01023-2 
Chiou-Wei, S. Z., Chen, Ch. F., \& Zhu, Z. (2008). Economic growth and energyconsumption revisited-evidence from linear and non linear Granger causality. Energy Economics, 30(6), 3063-3076. http://dx.doi.org/10.1016/j.eneco.2008.02.002

Chontanawat, J., Hunt, L. C., \& Pierse, R. (2008). Does energy consumption cause economic growth? Evidence from a systemic study of over 100 countries. Journal of Policy Modeling, 30, 209-220. http://dx.doi.org/10.1016/j.jpolmod.2006.10.003

Cleaver, K. M. (1993). A Strategy to Develop Agriculture in Sub-Saharan Africa and a Focus for the World Bank. World Bank Technical Paper Number 203, The World Bank, Washington, D.C. http://dx.doi.org/10.1596/0-8213-2420-9

Climent, F., \& Pardo, A. (2007). Decoupling factors on the energy-output linkage: The Spanish case. Energy Policy, 35, 522-528. http://dx.doi.org/10.1016/j.enpol.2005.12.022

Erdal, G., Erdal, H., \& Esengün, K. (2008). The causality between energy consumptionand economic growth in Turkey. Energy Policy, 36(10), 3838-3842. http://dx.doi.org/10.1016/j.enpol.2008.07.012

Erol, U., \& Yu, E. S. H. (1987a). Time series analysis of the casual relationships between US energyand employment. Resources Energy, 9, 75-89. http://dx.doi.org/10.1016/0165-0572(87)90024-7

Erol, U., \& Yu, E. S. H. (1987b). On the causal relationship between energy and income for industrializing countries. Journal of Energy Development, 13, 113-122.

Erol, U., \& Yu, E. S. H. (1989). Spectral analysis of the relationship between energy and income for industrialized countries. Journal of Energy Development, 13, 113-122.

Fatai, K., Oxley, L., \& Scrigeour, F. G. (2004). Modelling the causal relationship between energy consumption and GDP in New Zealand, Australia, India, Indonesia. The Philippines and Thailand Mathematics and Computers in Simulation, 64, 431-445. http://dx.doi.org/10.1016/S0378-4754(03)00109-5

Fuinhas, J. A., \& Marques, A. C. (2012). Energy consumption and economic growth nexus in Portugal, Italy,Greece, Spain and Turkey: An ARDL bounds test approach (1965-2009). Energy Economics, 34, 511-517. http://dx.doi.org/10.1016/j.eneco.2011.10.003

Ghosh, S. (2002). Electricity consumption and economic growth in India. Energy Policy, 30, 125-129. http://dx.doi.org/10.1016/S0301-4215(01)00078-7

Glasure, Y. U. (2002). Energy and national income in Korea: Further evidence on the role of omitted variables. Energy Economics, 24, 355-365. http://dx.doi.org/10.1016/S0140-9883(02)00036-1

Haggblade, S., Hazell, P., \& Brown, J. (1989). Farm-Non-Farm Linkages in Rural Sub-Saharan Africa. World Development, 17(8), 1173-1201. http://dx.doi.org/10.1016/0305-750X(89)90232-5

Halicioglu, F. (2009). An econometric study of $\mathrm{CO}_{2}$ emissions, energy consumption, income and foreign trade in Turkey. Energy Policy, 37, 1156-1164. http://dx.doi.org/10.1016/j.enpol.2008.11.012

International Energy Agency (IEA). (2011). Energy Statistics and Balances. International Energy Agency, Organisation for Economic Cooperation and Development, Paris, France. (Published annually in both printed and electronic formats).

Jobert, T., \& Karanfil, F. (2007). Sectoral energy consumption by source and economicgrowth in Turkey. Energy Policy, 35, 5447-5456. http://dx.doi.org/10.1016/j.enpol.2007.05.008

Jumbe, C. B. L. (2004). Cointegration and causality between electricity consumption and GDP: Empirical evidence from Malawi. Energy Economics, 26, 61-68. http://dx.doi.org/10.1016/S0140-9883(03)00058-6

Karanfil, F. (2008). Energy consumption and economic growth revisited: does the size of the unrecorded economy matter. Energy Policy, 36(8), 3029-3035. http://dx.doi.org/10.1016/j.enpol.2008.04.002

Kraft, J., \& Kraft, A. (1978). On the relationship between energy and GNP. Journal of Energy Development, 3, 401-403.

Kwakwa, P. A. (2012). Disaggregated Energy consumption and Economic growth in Ghana. International Journal of Energy economics and Policy, 2(1), 34-40.

Lee, C. C. (2006). The causality relationship between energy consumption and GDP in G-11 countries revisited. Energy Policy, 34, 1086-1093. http://dx.doi.org/10.1016/j.enpol.2005.04.023 
Lise, W., \& Van Montfort, K. (2007). Energy consumption and GDP in Turkey: is there a co-integration relationship? Energy Economics, 29, 1166-1178. http://dx.doi.org/10.1016/j.eneco.2006.08.010

Lloyd, T., Morrissey, O., \& Osei, R. (2001). Problems with Pooling in Panel Data analysis for Developing countries: The Case of Aid and Trade relationships. University of Nottingham CREDIT Research Paper $01 / 14$.

Lokolo, C. M. (1994). Donnees Sur L'EnergieetL'Agriculture au Cameroon. Unpublished data collection provided to FAO.

Lorde, T. K., \& Waithe., F. B. (2010). The importance of electrical energy for economic growth in Barbados. Energy Economics, 32, 1411-1420. http://dx.doi.org/10.1016/j.eneco.2010.05.011

Mahadevan, R., \& Asafu-Adjaye, J. (2007). Energy consumption, economic growthand prices: a reassessment using panel VECM for developed and developingcountries. Energy Policy, 35(4), 2481-2490. http://dx.doi.org/10.1016/j.enpol.2006.08.019

Mehrara, M. (2007). Energy consumption and economic growth: the case of oilexporting countries. Energy Policy, 35(5), 2939-2945. http://dx.doi.org/10.1016/j.enpol.2006.10.018

Mishra, V., Smyth, R., \& Sharma, S. (2009). The energy-GDP nexus: evidence from apanel of Pacific Island $\begin{array}{lllll}\text { countries. Resource and } & \text { Energy 210-220. }\end{array}$ http://dx.doi.org/10.1016/j.reseneeco.2009.04.002

Narayan, P. K., \& Smyth, R. (2005). Electricity consumption, employment and real income in Australia: Evidence from multivariate Granger causality tests. Energy Policy, 33, 1109-1116. http://dx.doi.org/10.1016/j.enpol.2003.11.010

Narayan, P. K., \& Smyth, R. (2008). Energy consumption and real GDP in G7 countries: new evidence from panel cointegration with structural breaks. Energy Economics, 30, 2331-2341. http://dx.doi.org/10.1016/j.eneco.2007.10.006

Odhiambo, N. M. (2009). Energy consumption and economic growth nexus inTanzania: an ARDL bounds testing approach. Energy Policy, 37(2), 617-622. http://dx.doi.org/10.1016/j.enpol.2008.09.077

Oh, W., \& Lee, K. (2004). Energy consumption and economic growth in Korea: Testing the causality relation. Journal of Policy Modeling, 26, 973-981. http://dx.doi.org/10.1016/j.jpolmod.2004.06.003

Olayeni, O. R. (2012). Energy consumption and Economic Growth in sub-Saharan Africa: An Asymetric $\begin{array}{lllll}\text { Cointegration Analysis. } & \text { International }\end{array}$ http://dx.doi.org/10.1016/S2110-7017(13)60050-5

Payne, J. E. (2009). On the dynamics of energy consumption and output in the US. Applied Energy, 86(4), 575-577. http://dx.doi.org/10.1016/j.apenergy.2008.07.003

Pereira, A. M., \& Pereira, R. M. M. (2010). Is fuel-switching a no-regrets environmentalpolicy? VAR evidence on carbon dioxide emissions, energy consumption andeconomic performance in Portugal. Energy Economics, 32, 227-242. http://dx.doi.org/10.1016/j.eneco.2009.08.002

Sari, R., Ewing, B. T., \& Soytas, U. (2008). The relationship between disaggregate energy consumption and industrial production in the United States: An ARDL approach. Energy Economics, 30, 2302-2313. http://dx.doi.org/10.1016/j.eneco.2007.10.002

Soytas, U., \& Sari, R. (2006). Energy consumption and income in G7 countries. Journalof Policy Modeling, 28, 739-750. http://dx.doi.org/10.1016/j.jpolmod.2006.02.003

Soytas, U., \& Sari, R. (2009). Energy consumption, economic growth, and carbonemissions: challenges faced by an EU candidate member. Ecological Economics, 68(6), 1667-1675. http://dx.doi.org/10.1016/j.ecolecon.2007.06.014

Stern, D. (1993). Energy and economic growth in the USA. A multivariate approach. Energy Economics, 15, 137-150. http://dx.doi.org/10.1016/0140-9883(93)90033-N

Stoneman, C., \& Robinson, P. (1988). Economic Modeling for LEAP: Background and Methodology.in Hosier.

Tamba, J. G., Njomo, D., Limanond, T., \& Ntsafack, B. (2012). Causality analysis of diesel consumptionand economic growth in cameroon. Energy Policy, 45, 567-575. http://dx.doi.org/10.1016/j.enpol.2012.03.006

Thoma, M. (2004). Electricity energy usage over the business cycle. Energy Economics, 26, 463-485. http://dx.doi.org/10.1016/j.eneco.2004.04.006 
Tsani, S. Z. (2010). Energy consumption and economic growth: a causality analysis for Greece. Energy Economics, 32(3), 582-590. http://dx.doi.org/10.1016/j.eneco.2009.09.007

World Data Bank African Development Indicators. (2011). Retrieved from http://data.worldbank.org/data-catalog/africa-development-indicators

Wolfe-Rufael, Y. (2005). Energy demand and economic growth. Journal of Policy Modeling, 27, 891-903. http://dx.doi.org/10.1016/j.jpolmod.2005.06.003

Wolde-Rufael, Y. (2006). Electricity consumption and economic growth: A time series experience for 17 African countries. Energy Policy, 34, 1106-1114. http://dx.doi.org/10.1016/j.enpol.2004.10.008

Wolde-Rufael, Y. (2009). Energy consumption and economic growth: The experience of African Countries revisited. Energy Economics, 31, 217-224. http://dx.doi.org/10.1016/j.eneco.2008.11.005

Yang, H. Y. (2000). Anote on the causal relationship between energy and GDP in Taiwan. Energy Economics, 22, 309-317. http://dx.doi.org/10.1016/S0140-9883(99)00044-4

Yuan, J.-H., Kang, J.-G., Zhao, C.-H., \& Hu, Z.-G. (2008). Energy consumption andeconomic growth: Evidence from China at both aggregated and disaggregated levels. Energy Economics, 30, 3077-3094. http://dx.doi.org/10.1016/j.eneco.2008.03.007

Yu, E. S. H., \& Hwang, B. K. (1984). The relationship between energy and GNP: Further results. Energy Economics, 6, 186-1990. http://dx.doi.org/10.1016/0140-9883(84)90015-X

Yu, E. S. H., \& Choi, J. Y. (1985). The causal relationship between energy and GNP: An international comparison. Journal of Energy Development, 10, 249-272.

Yu, E. S. H., Choi, P. C. Y., \& Choi, J. Y. (1988). The relationship between energy and employment: a re-examination. Energy Systems Policy, 11, 287-295.

Yu, E. S. H., \& Jin, J. C. (1992). Cointegration tests of energy consumption, income and employment. Resources Energy, 14, 259-266. http://dx.doi.org/10.1016/0165-0572(92)90010-E

Zachariadis, T. (2007). Exploring the relationship between energy use and economicgrowth with bivariate models: New evidence from G-7 countries. Energy Economics, 29, 1233-1253. http://dx.doi.org/10.1016/j.eneco.2007.05.001

Zamani, M. (2007). Energy consumption and economic activities in Iran. Energy Economics, 29, 1135-1140. http://dx.doi.org/10.1016/j.eneco.2006.04.008

Ziramba, E. (2009). Disaggregate energy consumption and industrial production in 'south Africa. Energy Policy, 37(2009), 2214-2220. http://dx.doi.org/10.1016/j.enpol.2009.01.048

\section{Note}

Note 1. For a detailed literature survey on the relationship between energy consumption and economic growth, see beginning from the pioneer works of Kraft and Kraft (1978), Akarca and Long (1979) found a unidirectional causality running from gross national product to energy in USA. Akarca and Long (1980), Erol and Yu (1987a), $\mathrm{Yu}$ and Choi (1985) and Yu and Hwang (1984) among others found no causal relationship between income proxied by GNP and energy consumption while Erol and Yu (1987b, 1989), Yu and Jin (1992) and Yu, Choi and Choi. (1988) found evidence in favour of neutrality of energy consumption and employment. More importantly, none of the studies considered the possible effects on components of GDP as examined in this study.

\section{Copyrights}

Copyright for this article is retained by the author(s), with first publication rights granted to the journal.

This is an open-access article distributed under the terms and conditions of the Creative Commons Attribution license (http://creativecommons.org/licenses/by/3.0/). 